\title{
Rebuilding Microbiome for Mitigating Traumatic Brain Injury: Importance of Restructuring the Gut-Microbiome-Brain Axis
}

\author{
Akash K. George $^{1,2} \cdot$ Jyotirmaya Behera ${ }^{3} \cdot$ Rubens P. Homme $^{1,2} \cdot$ Neetu Tyagi $^{3} \cdot$ Suresh C. Tyagi $^{2} \cdot$ Mahavir Singh $^{1,2}{ }^{D}$
}

Received: 15 December 2020 / Accepted: 10 March 2021 / Published online: 27 March 2021

(C) Springer Science+Business Media, LLC, part of Springer Nature 2021

\begin{abstract}
Traumatic brain injury (TBI) is a damage to the brain from an external force that results in temporary or permanent impairment in brain functions. Unfortunately, not many treatment options are available to TBI patients. Therefore, knowledge of the complex interplay between gut microbiome (GM) and brain health may shed novel insights as it is a rapidly expanding field of research around the world. Recent studies show that GM plays important roles in shaping neurogenerative processes such as blood-brainbarrier (BBB), myelination, neurogenesis, and microglial maturation. In addition, GM is also known to modulate many aspects of neurological behavior and cognition; however, not much is known about the role of GM in brain injuries. Since GM has been shown to improve cellular and molecular functions via mitigating TBI-induced pathologies such as BBB permeability, neuroinflammation, astroglia activation, and mitochondrial dysfunction, herein we discuss how a dysbiotic gut environment, which in fact, contributes to central nervous system (CNS) disorders during brain injury and how to potentially ward off these harmful effects. We further opine that a better understanding of GM-brain (GMB) axis could help assist in designing better treatment and management strategies in future for the patients who are faced with limited options.
\end{abstract}

Keywords 1-Carbon metabolism $\cdot$ Central nervous system $\cdot$ Ocular function $\cdot$ Retinal remodeling $\cdot$ Brain trauma

\section{Introduction}

Traumatic brain injury (TBI) occurs due to an external force causing skull damage which could invariably affect the brain [1]. The trauma leading to brain injury can be broadly categorized as an impact or a non-impact event depending upon whether the external object had a direct contact with the head (impact) or was it a non-impact force like the blast waves or a rapid acceleration, and deceleration (non-impact) with the head [2]. In the USA, frequency of TBI occurs every $15 \mathrm{~s}$ (roughly about 1.7 million new TBI cases/year) and costs

A part of this work was supported by NIH grants AR-71789, HL139047, and DK116591.

Mahavir Singh

mahavir.singh@louisville.edu; gene2genetics@gmail.com

1 Eye and Vision Science Laboratory, Department of Physiology, University of Louisville School of Medicine,

Louisville, Kentucky 40202, USA

2 Department of Physiology, University of Louisville School of Medicine, Louisville, Kentucky 40202, USA

3 Bone Biology Laboratory, Department of Physiology, University of Louisville School of Medicine, Louisville, Kentucky 40202, USA more than US $\$ 77$ billion/year [3]. In brief, TBI events are responsible for 50,000 deaths together with 80,000 individuals that are left with permanent disabilities each year [4-7]. It is believed that the frequency of brain injury is estimated to be higher than any other type of diseases such as Parkinson's disease, multiple sclerosis, AIDS, and breast carcinoma [3]. For example, motor-vehicle or traffic-related accidents constitute $17 \%$ cases while walking-falls are responsible for $35 \%$ of cases in USA [4-7]. As per one estimate 130,000 children in the age between 5 and 18 years suffered from sport-related concussions [8]. Besides, blast injury was the most common cause of TBI-related event that was observed among the military personnel [9]. In recent years, several experimental animal models have been developed to replicate human TBI pathophysiological aspects employing the pre-clinical settings [10] including fluid percussion, weight-drop injury, and controlled cortical impact (CCI). These animal models are routinely used in simulating TBI-related events in small animals with characteristics of mild or severe TBI. In fact, these models remain the workhorses for studying characteristic features of the primary, as well as secondary brain injuries in humans [11].

An acquired insult during TBI could potentially change various structural components of the brain resulting in 
temporary or even permanent brain impairment $[12,13]$. Interestingly, GM and its role(s) in various system disorders has recently been the major focus area of research worldwide. For example, previous work reveals that GM plays important roles in neurogenerative processes such as formation of BBB, myelination, neurogenesis, and microglial maturation [14]. It has been shown that microbiome also modulates many aspects of our behavior since GM is involved in the modulation of cellular and molecular processes by balancing microbial eubiosis and dysbiosis condition and also involved in the progression of TBI-induced pathologies including BBB permeability, immune response to neuroinflammation, astroglial activation, and mitochondrial dysfunction (Fig. 1) [14]. Currently, efficacious treatments for TBI patients are acutely lacking [15-17]. Additionally, gut dysbiosis is known to exacerbate behavioral impairment as shown in studies that employed animal models of TBI and the spinal cord injury [18-21]. Furthermore, the dysbiotic milieu negatively affects the post stroke recovery [22-25]. Treatments for TBI and related disorders are severely limited, but recent research shows that microbiome transplants could mitigate CNS damage and functional impairments in spinal cord injury and stroke in animals [18]. In addition, probiotics were shown to reduce the rate of infections and time spent in intensive care units of hospitalized patients suffering from the brain trauma $[18,26,27]$. Thus, establishment of a protective, that is, eubiotic GM, is a promising therapeutic avenue since the brain injuries induce dysbiosis (Fig. 2). Reiner and colleagues 2014 reported that Novel CB2 Inverse Agonist SMM-189 reduce motor, visual, and emotional deficits after closed-head mild traumatic brain injury mouse model via mitigation of microglial inflammatory action [28]. ER stress was found to be increased early in juvenile rats exposed to TBI and that these rats developed tau oligomers over the course of 30 days and had significant short-term and spatial memory deficits following injury [29]. Treangen and colleagues suggested that acute bacterial dysbiosis within the gut microbiome was observed after TBI post-injury in mice [30]. The overall researched layout is represented in Fig. 2. However, postTBI associated ocular and brain dysfunction via direct regulation of altered gut microbiome homeostasis is still needed to be demonstrated. This review discusses how GM alterations during post TBI contribute to CNS dysfunction and how to potentially target GM for therapeutic benefits in patients.

\section{An Overview of Traumatic Brain Injury (TBI)}

TBI is defined as an alteration in brain functions that is provoked often by an external force. Unfortunately, it remains the main cause of injury-related death, disability, and mental disorders, thus representing a major public health issue globally [31-34]. In the year 2013 alone, a total of approximately 2.8 million TBI-related emergency department visits, hospitalizations, and deaths were registered in the USA [35]. Unfortunately, it is also one of the most prevalent injury types in many industrialized countries [36]. Although there has been an overall decline in TBI mortality because of an improved treatment modality over the years; however, there is substantial increase in the number of individuals living with disabilities as a direct result of TBI [37-41]. At cellular levels, TBI pathophysiology is characterized by acute necrotic or delayed apoptotic neuronal death, cytokine and chemokine production, infiltration of peripheral immune cells, and activation
Fig. 1. TBI induced dysbiosis via the gut microbiome brain (GMB) axis. The GMB-axis could potentially contribute, and further worsen the injury profile by promoting dysbiosis over eubiosis wherein harmful microbes in the gut can lead to an increase in neuroinflammation, mitochondrial dysfunction, oxidative stress, microglial activation, behavioral, and cognitive impairment, and intestinal wall permeability.

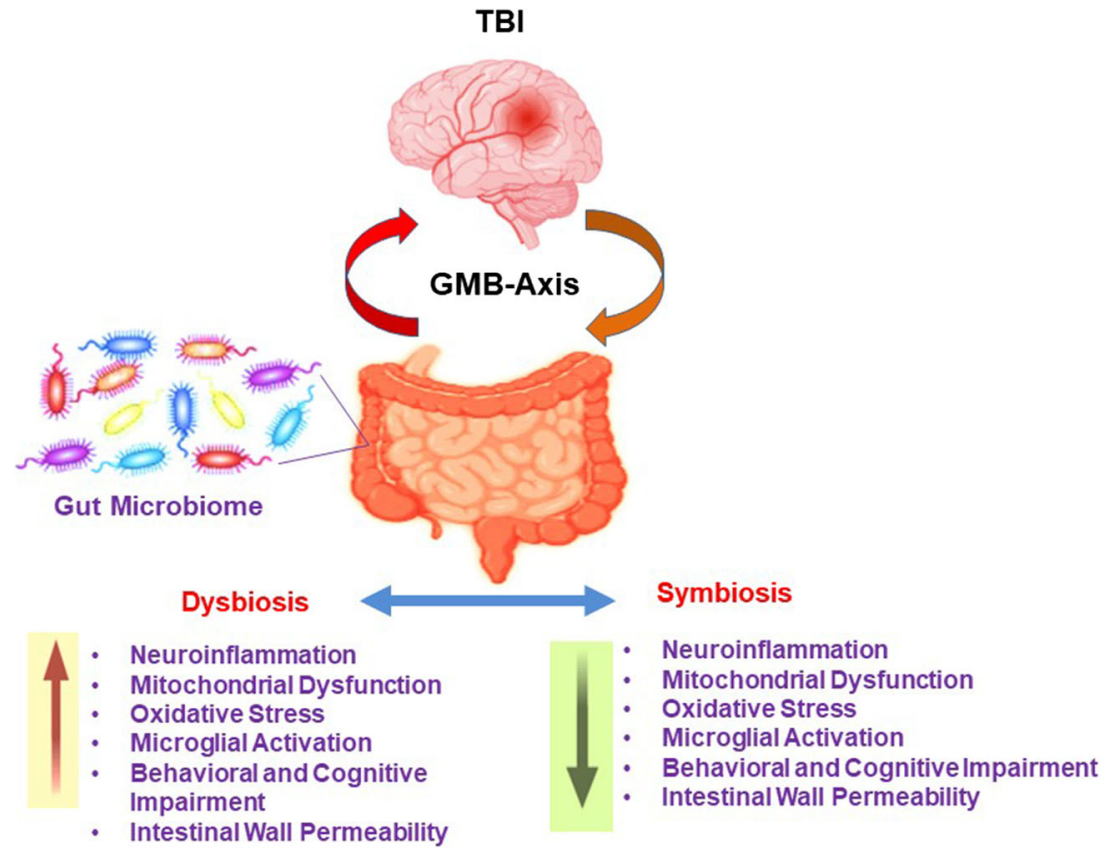


Fig. 2. Resolution of the gut dysbiotic environment. Treatment with probiotics may help break the vicious dysbiotic cycle thus reducing the impact of brain injury, and hence improve substantially the TBI-related biochemical, pathological, and behavioral markers.

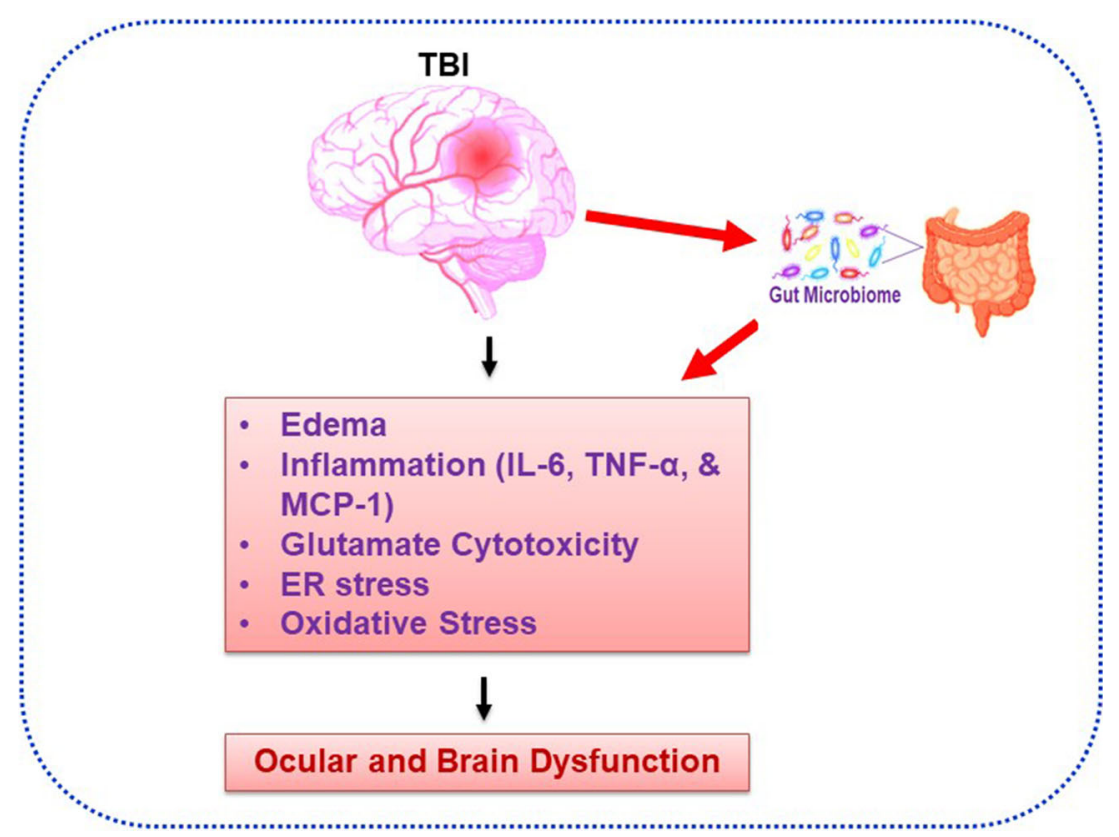

of astrocytes and microglia that lead to a variety of brain, and visual problems [42-45]. The survivors often suffer from debilitating secondary injury conditions including cognitive deficits pertaining to their memory, attention, executive function, speed of information processing, and personality changes that are best characterized as dysexecutive syndromes involving social comportment, cognition, and motivated behavior and increased relative rates of psychiatric disorders, particularly depression and anxiety along with ocular dysfunction [15-17, 46, 47]. Despite past research accomplishments in TBI pathophysiology, much remains to be discovered regarding mechanistic understanding into the heterogeneous nature of brain injury-related neuropathologies, behavioral, and cognitive impairments. Again, as discussed earlier efficacious therapeutics for TBI-induced maladies are lacking [48-50]. Therefore, it is vital to consider novel treatment strategies to combat TBI-related disabilities, and in this context manipulation of GM by gut eubiotic therapeutic modalities could serve as means of captivating this expanding avenue, against the TBI-induced medical condition [51] (Figures 1 and 2).

\section{Homocysteine, its Metabolism, and TBI Complications}

Homocysteine (Hcy) is a sulfur containing non-proteinogenic amino acid derived from the essential amino acid methionine (Met) (Fig. 3). The catabolism of Met can be disrupted by factors like lifestyle, stress, aging, or genetic abnormalities leading to hyperhomocysteinemia (HHcy). Dietary Met is first converted to S-adenosyl methionine (SAM), which is changed to S-adenosyl Hcy (SAH). Then SAH leads to the production of Hcy, which is further re-methylated back to Met wherein vitamin B12 serves as a co-factor, and the cycle continues [52]. Under the condition of either low cysteine or saturation of Hcy back to re-methylation, then Hcy can be further catabolized via the trans-sulfuration pathway into cysteine. In this rate-limiting step, Hcy is first converted to cystathionine with the help of cystathionine $\beta$-synthase (CBS) where vitamin B6 is an essential co-factor. Subsequently, cystathionine is converted to cysteine by cystathionine $\gamma$-lyase (CSE). Cysteine is then broken down to taurine, glutathione, and hydrogen sulfide $\left(\mathrm{H}_{2} \mathrm{~S}\right)$ (Ref-9 (Fig. 3). In its excess amount when it starts accumulating, Hcy is highly neurotoxic to astrocytes and neurons $[53,54]$. Normally, it is continuously eliminated either via its re-methylation back to Met or via trans-sulfuration to cystathionine production. However, Hcy can accumulate under certain circumstances such as during folate deficiency, aging, occurrence of a mutation in methylenetetrahydrofolate reductase (MTHFR) gene, or under physical or emotional stress conditions [55-60]. When Hcy builds up (also known as HHcy), it invariably leads to BBB dysfunction and microvascular disorders [61]. It also increases $\mathrm{NAD}(\mathrm{P}) \mathrm{H}$ oxidase activity which in turn triggers microglia activation thus stimulating the secretion of pro-inflammatory molecules [61-64].

A recent study demonstrated that Met-treated HHcy in a TBI mouse model exhibited increased oxidative stress and BBB dysfunction. The phenotype promoted infiltration of inflammatory cells into the cortex as also emphasized here in Figs. 1 and 2 [63-65]. The study also suggested that HHcy was implicated in visual dysfunction. The previous study has clearly indicated that HHcy is a potent risk factor for retinal arteriosclerosis [51, 66], exudative age-related macular degeneration (AMD) [67], and macular and optic atrophy due to retinal vascular occlusion or non-arteritic ischemic optic neuropathy [68] and glaucoma [69]. In fact, cross-sectional studies have demonstrated that there is a 


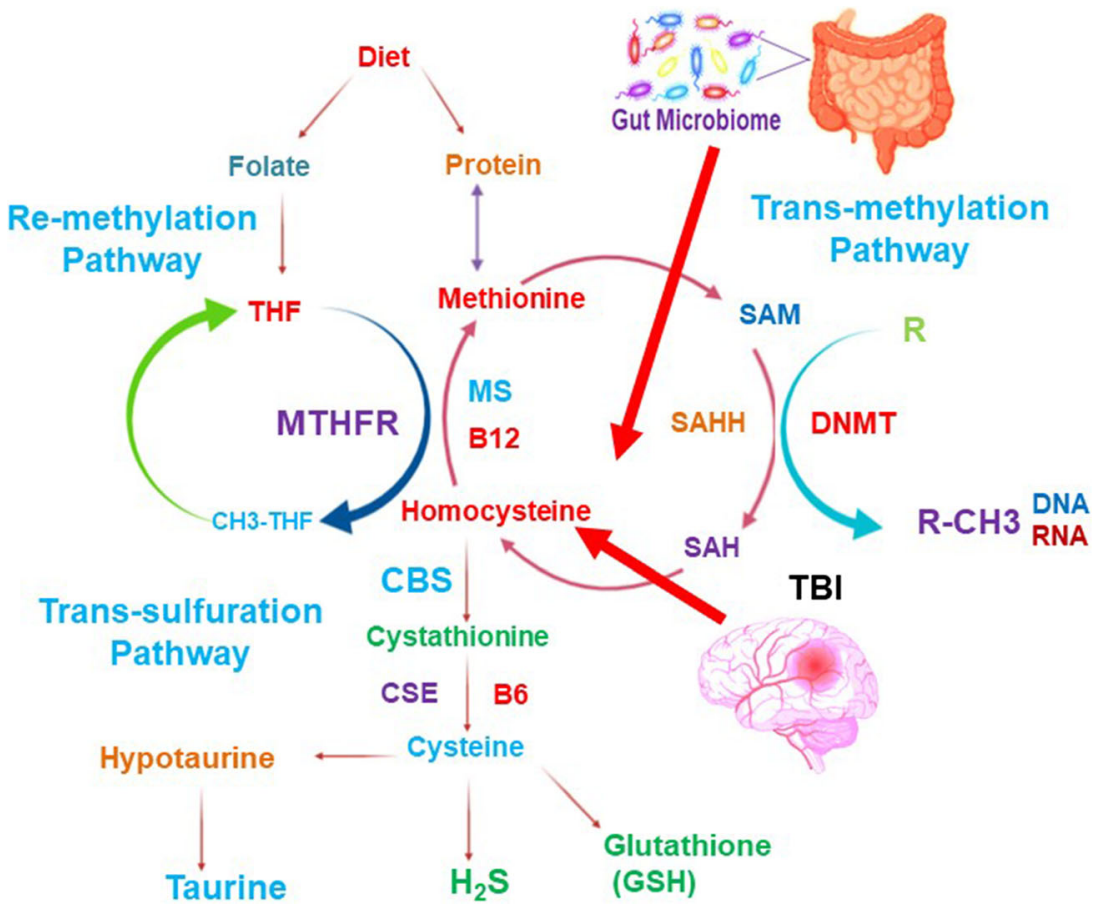

Fig. 3. Hcy metabolic pathways. Hcy resides at the intersections of remethylation and trans-sulfuration pathways. In the re-methylation pathway, tetrahydrofolate (THF) is converted to methyl $\left(\mathrm{CH}_{3}\right)$ THF by methylenetetrahydrofolate reductase (MTHFR). The methyl group is donated to Hcy, and in the presence of methionine synthase (MS), and B12, it is converted to Met. Met is used further in many methyl transfer reactions. When the diet is replete with Met, Hcy is converted via transsulfuration pathway to cystathionine by cystathionine $\beta$ synthase (CBS),

and then again to cysteine via the action of cystathionase (CSE) in the presence of B6. Finally, cysteine is converted to several beneficial downstream products such as glutathione (GSH), and taurine which are essential for brain, and retinal functions. Abbreviations: SAHH; Sadenosyl homocysteine hydrolase, SAH; S-adenosyl homocysteine, R; represents a carbon-based group, DNA; deoxyribonucleic acid, RNA; deoxyribonucleic acid.

strong association between HHcy and exudative neovascular AMD [70]. Thus, HHcy appears to exacerbate TBI outcome suggesting that Hcy dysregulation may be a significant biological variable that could contribute to TBI pathophysiology and ocular disease conditions (Fig. 3). In addition, Zinno and colleagues suggested that dietary supplementation of dairy matrices containing natural folic acid could mitigate the plasma homocysteine (Hcy) and SAM levels and found to restore the fecal microbiota composition in the hyperhomocysteinemic (HHcy) mouse model (Fig. 3) [71]. However, the direct connection between HHcy, associated post-TBI outcomes such as neuroinflammation, BBB dysfunction, and cognitive deficits via modulation of gut microbiota homeostasis needs to be explored. Therefore, further research is warranted to understand the mechanism(s) of HHcyassociated multifactorial post-TBI linked outcomes.

\section{Gut Microbiome Brain (GMB) Axis}

The human intestine consists of more than 1000 types of microbes from at least 4000 different species [72-75]. Hence, alterations in their relative composition have been known to play definitive roles in the pathogenesis of many system disorders like diabetes, obesity, inflammatory bowel disease, Crohn's disease, Alzheimer's disease, anxiety, and depression [76-83]. In recent years, there has been an increasing interest in studying interactions between the brain, gastrointestinal (GI) tract, and its microbiome and the bidirectional relationship between these systems [84] (Fig. 1). A deeper insight into the brain-gut crosstalk revealed the existence of a complex communication channel that not only ensures proper wellbeing of the gastrointestinal homeostasis but also likely to have multiple effects on the overall brain functioning such as higher cognitive function and motivation. The complexity of these interactions between the brain and gut is presumably through "gut-brain axis" ([85]. By realizing the importance of microbiome in modulating health, the gut-brain axis has been renamed as the GMB axis, which represents a complex network of communication between the gut, intestinal microbiome, and brain that seem to modulate immune system, gastro-intestinal tract, behavior, stress response, and CNS functions [15-17, 85-94] (Fig. 2). This bidirectional communication includes the enteric nervous system, autonomic nervous system, central nervous system, and the hypothalamic-pituitary-adrenal axis; however, the hypothalamic pituitary adrenal axis is considered as the core stress 
efferent axis [85, 95-97]. It was previously shown that GM regulates intestinal function and health but later accumulating evidence indicated that it could also influence the immune and nervous systems and vice versa [98].

Elderly individuals with lower diversity of microorganisms have strong connection with various system disorders [99]. Although quite a literature has already been published, it is still an evolving area of great significance where important links between diet, microbes, and cognition should be emphasized in detail as we make further progress. The influence of the microbiome on obesity and metabolic syndrome is also being increasingly recognized. It has been proven in the meantime that gut and brain do communicate with each other via several routes including the vagus nerve, immune system, enteric nervous system, and or by way of various microbial metabolic processes [100-102]. These microbiomedependent processes have also been shown to include myelination, adult hippocampal neurogenesis, and microglia activation [103-105]. Reports show that animals featuring normal intestinal microbiome that are subject to no external influences develop inflammation in their brain $[101,102]$. There are, in fact, already reports of the link between an intestinal dysbiosis and the non-infectious uveitis. Furthermore, the microbiome alteration with either germ-free rearing or treatment with oral metronidazole and ciprofloxacin resulted in reduced uveitis [106-110]. Another study showed that fecal microbial transplantation from Behcet's disease patients into an autoimmune uveitis-prone mouse model worsened intraocular inflammation [111, 112].

Interestingly, obesity has been called a psychiatric disease and is highly linked with depression and other neuropsychiatric disorders [113-115]. Similarly, schizophrenia has been linked to intestinal inflammation and gastro-jejunal ulcers $[115,116]$. Furthermore, deregulation in the GM that is associated with age-related decline in sensory, motor, and higher cognitive functions leads to age-related neurodegenerative disorders [117-121]. In recent years, researchers have proposed a potential role for pathogenic microbes, including those derived from gut in the development or exacerbation of Alzheimer's disease [122-125]. There are many studies depicting alterations in the GM that are associated with neurological disorders, multiple sclerosis, and the Parkinson's disease [126-133]. Similarly, unhealthy microbiome has been associated with the disruption of the ocular tissues, exacerbation of diabetic retinopathy, age-related macular degeneration, choroidal neovascularization, uveitis, glaucoma, and Sjogren's syndrome $[134,135]$. On the other hand, Treangen and colleagues in 2018 suggested the overall impact of TBI on bacterial dysbiosis, and they went on to show that microbial changes occur $24 \mathrm{~h}$ after TBI in mice, indicating that $\mathrm{CCI}$ causes a rapid shift in relative abundance of many species including Lactobacillus gasseri, Ruminococcus flavefaciens, and Eubacterium ventriosum that are commonly seen in the human GM [30]. These results suggested that probiotics administration could be a therapeutic strategy for individuals with post-traumatic stress disorders such as TBI.

\section{GMB-Axis in CNS Injuries}

TBI-related pathophysiological effects have been increasingly studied that are directly associated with intestinal dysfunction and these effects represent an important consequence to the host because the GMB-axis supposedly ensures major bidirectional communication pathway between the brain and gastrointestinal tract incorporating both afferent and efferent signals which involve neuronal, hormonal, and immunologic cross-talk. Such bidirectional interactions can result in sequelae such as chronic fatigue of the gastrointestinal system including its disability to function properly [136-139] [140, 141] (Fig. 1). In the mouse model of brain, and spinal cord injury, CNS injury does upset the intestinal wall motility, and its permeability along with changes in the GM composition which ultimately led to gut dysbiosis [136, 137, 142-144].

Conversely, it is also reported that gut dysbiosis influences the traumatic CNS injury and its pathophysiology $[145,146]$. In a traumatic spinal injury model, a study showed that gut microbiota composition was altered wherein there was a decrease in the population of Bacteroidetes but an increase in Firmicutes amount, and it was associated with an impairment in locomotor function [147]. Further, in a CCI rodent model of moderate TBI, gut microbiota composition (decrease in Firmicutes and increase in Bacteroidetes and Proteobacteria) was altered following $2 \mathrm{~h}$ of injury along with increased postinjury lesion volume [148]. On the other hand, the study explains that gut eubiosis controlled reversible DNA methylation through activating DNA methyltransferase (DNMT) and phosphatidylethanolamine methyltransferase (PEMT) and that allows normal gene regulation. But the irreversible DNA methylation causes HHcy during dysbiosis condition and disrupts the normal gene regulation which could be responsible for cardiovascular metabolic syndrome (141) (Fig. 4). However, understanding the relationship between TBIinduced gut dysbiosis and altered gene regulation needs to be studied. Howard and colleagues suggested that severely injured patients with polytrauma established the relation between gut dysbiosis and post-injury in human patients. They have shown that $72 \mathrm{~h}$ of post-injury was associated with a decrease in Bacteroidales, Fusobacteriales, and Verrucomicrobiales but an increase in Clostridiales and Enterococcus populations [149]. These findings provide the complex relation between and multiple disease outcomes, revealing the notion that bacterial populations indeed influence the post-injury mediated neuro-pathophysiology and functional impairment via dysbiosis-dependent mechanisms [150-156]. 


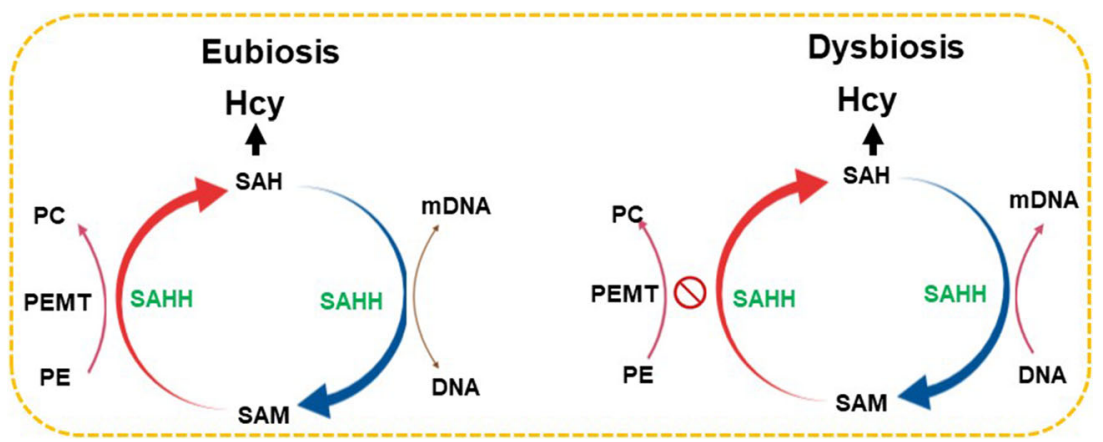

Fig. 4. Eubiosis versus dysbiosis: Epigenetic mechanisms favor reversible and irreversible DNA methylation pattern in a given cell. During eubiosis condition, DNMT- and -mediated reversible DNA methylation allows normal gene regulation. However, irreversible DNA methylation causes HHcy due to dysbiotic condition and disrupts normal gene expression. Abbreviations: $P E$ phosphatidylethanolamine, $P C$ phosphatidylcholine, $P E M T$ phosphatidylethanolamine methyltransferase, $S A M$ S-adenosyl methionine, SAH S-adenosyl homocysteine, SAHH Sadenosyl homocysteine hydrolase, $m D N A$ methylated DNA, and DNMT DNA methyltransferase

\section{Interplay of Transforming Growth Factor/Bone Morphogenetic Protein Signaling During TBI and Its Possible Link with the GM}

Transforming growth factor (TGF) superfamily members are altered following TBI in the rodent species [157-163]. It has been reported that an increased TGF- $\beta 1$ and TGF- $\beta 2$ protein levels were described in human spinal cord injuries and BMP7 mRNA and protein levels in rat spinal cord injury [164-166]. Despite accumulated evidence, the precise role of this signaling system, and the interplay between the TGF $\beta$, and BMP branches in the context of TBI pathophysiology are still not fully understood.

An early expression of BMP-6 in neurons of the hippocampus and cortex in normal adult rat brains that were subjected to TBI was demonstrated which was followed by pronounced expression in astroglia located to the lesion became obvious $48 \mathrm{~h}$ post-injury. The glia cells were found to be distributed around lesion, thus demarcating the injured tissue from the normal brain area. Further, double labeling by immunohistochemistry revealed that the major glial sources for BMP-6 were reactive astrocytes together with a few ED1(+) or W3/ $13(+)$ cells that also co-expressed BMP-6 protein. Subsequently, it was noticed that BMP-6 expression in neurons located to hippocampus and cortex of the lesioned hemisphere was upregulated 3 days post-injury suggesting that BMP-6 might be involved in astrogliosis following TBI [167]. Similarly, it was shown by others the distribution of TGF- $\beta 1$ and BMP- 6 in the brain of rats subjected to a mild and reversible ischemic damage produced by a 20 -min occlusion of both carotid arteries without occlusion of the vertebral arteries. The researchers selected this model to study how the expression of trophic factor of the TGF- $\beta$ superfamily changes in neurons that recover from a transient insult. Immunocytochemical analysis showed a loss of TGF- $\beta 1$ in neurons of all hippocampal subfields immediately after the ischemic period, followed by a recovery of immunoreactivity in CA1 and CA3 neurons after reperfusion. BMP-6 immunoreactivity was also lost in most of the hippocampal neurons, but immunostaining became particularly intense in the interstitial space after both ischemia and reperfusion. An interstitial localization of BMP- 6 was also observed in the cerebral cortex, particularly after reperfusion. Interestingly, mild ischemia also induced substantial changes in the expression of TGF- $\beta 1$ and BMP-6 within the cerebellar cortex. In control animals, these factors appeared to be localized in granule cells and Purkinje cells, whereas the molecular layer was not immunepositive. Both TGF- $\beta 1$ and BMP- 6 were highly expressed in the interstitial spaces of the cerebellar cortex either $20 \mathrm{~min}$ after ischemia or $20 \mathrm{~min}$ after reperfusion. Taken together, these results suggest that a mild and reversible ischemia stimulates the release of BMP- 6 from neurons into the interstitial space [168].

Disruption of TGF- $\beta$ /BMP signaling cascade alters GM size, and its composition via ligand binding, and activation of heterodimer receptors, downstream Sma and Mothers against decapentaplegic (SMAD) homologs transcriptional regulators and co-activators [169]. The above signaling regulates intestinal immunity and also manages control of the intestinal bacterial proliferation that is important for the regulation of lifespan in Caenorhabditis elegans since it is involved in the shaping of the GM [169-182]. In corroboration with previous findings, in the present review, we thus hypothesize that targeting TGF- $\beta$ /BMP signaling cascade could prove as a milestone for effective future treatment strategy in the mouse model of TBI. In short, we believe that through modulation of GM via probiotics administration in the injured mouse model could counteract the downstream cellular and molecular events (neuronal death, inflammation, and BBB damage) of TGF- $\beta$ /BMP signaling, and thereby it might be able to restore the brain and ocular damaging events (Fig. 5). 


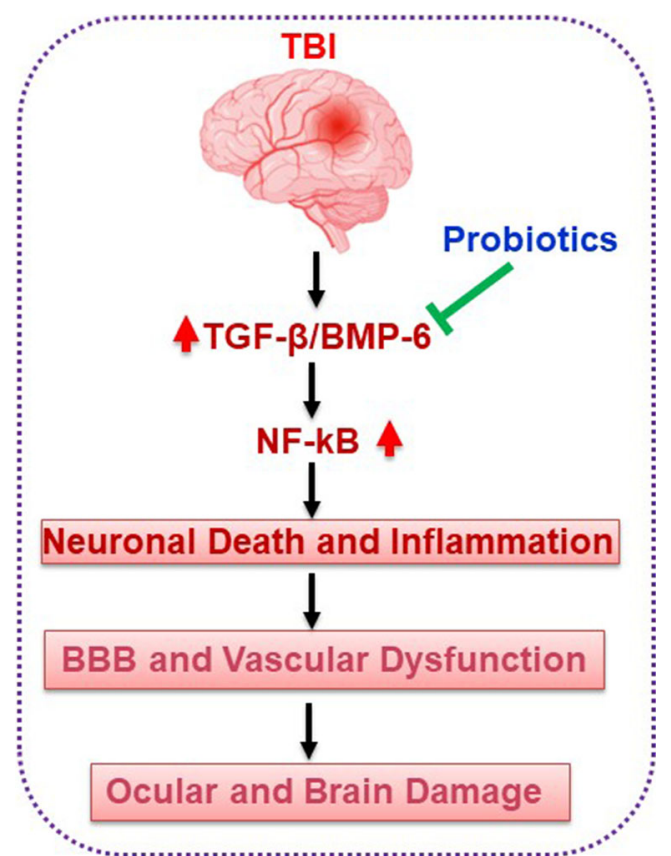

Fig. 5 Diagram illustrating TGF- $\beta$ /BMP-6-mediated effects during TBI. Activation of the NF-kB results in neuronal cell death, inflammation, BBB break-down followed by vascular dysfunction. Many of these deleterious effects could be mitigated by timely probiotics treatment. Abbreviations: TBI

\section{Gut Microbiome (GM) as Potential Diagnostic and Therapeutic Target for TBI}

Understanding the gut microbiota composition and its alteration during dysbiosis may help in designing therapeutics having more efficacy and the relevant diagnostic tools for treating post-TBI complications and outcomes in affected TBI patients. Houlden and colleagues in 2016 found a positive correlation between the degree of gut dysbiosis and post-TBI injury in the "closed-head-impact" pre-clinical mouse model. In this regard, manipulation of the GM via microbiota transplants and pre- or probiotics consumption could, in fact, provide an exciting treatment against brain injuries (Fig. 2). As previous studies suggested that GM was substantially changed during the 24-72 $\mathrm{h}$ window period post-TBI injury; therefore, eubiotic therapeutic strategies could fundamentally shift the altered GM to a beneficial one and thus mitigate post TBIassociated secondary injury and the exaggerated damage response. [147-149].

As mentioned above, pre-clinical studies support the concept that microbiota transplants could be a valuable therapeutic tool to reduce brain lesion size and can help improve health outcomes in animal models such as shown in a mouse model of ischemic stroke to restore the microglial function [183, 184]. Probiotic and the microbial-derived metabolites and short-chain fatty acid (SCFA) products like butyrate, propionate, and acetate may also help modulate mitochondrial homeostasis, and energy production [185]. Interestingly, along with dietary ketones, these metabolites work as the alternative energy sources for the injured brain towards improving mitochondrial bioenergetics in post-TBI and SCI injury models [186]. The gut microbiota-derived SCFA, especially the butyrate, acts as a potential histone deacetylation (HDAC) inhibitor, thereby offering a robust neuroprotection following post-TBI insults [187]. For example, probiotic Clostridium butyricum-derived butyric acid in fact did improve neurological deficits and attenuated neurodegeneration, BBB impairment, and reduced brain edema through the GMB axis in mouse model of weight-drop impact head injury and cerebral ischemia [188]. Also, VSL\#3, is the mixture of eight friendly bacterial strains (4 strains of Lactobacillus viz. Lactobacillus acidophilus, Lactobacillus plantarum, Lactobacillus casei, and Lactobacillus delbrueckii subspecies bulgaricus, 3 strains of Bifidobacterium viz. Bifidobacterium breve, Bifidobacterium longum, and Bifidobacterium infantis, and 1 strain of Streptococcus viz. Streptococcus salivarius subspecies thermophilus. VSL\#3 is considered as an advanced probiotic medical food [189]. It mainly improves gut microbial eubiosis and reduces intestinal barrier function, through improving tight junction protein (TJP) expression, and modulation of anti-inflammatory cytokine expression that is required for the physiological function of the host [190]. When VSL\#3 was provided to the spinal cord injury, mouse model on the same day of injury was shown to improve the post-injury neuropathology. Furthermore, this probiotic improved the locomotor recovery and triggered an increase in the number of Treg cells, thus offering a protective immune environment [19].

In human preclinical trials, post-TBI injury patients when supplemented with Lactobacilli-rich probiotics within the first $48 \mathrm{~h}$ of hospital admission, and it was demonstrated that patients had a substantial decrease in their gastrointestinal dysfunction along with less incidence of ventilator-associated pneumonia, thus reducing the nosocomial infection rate [27, 191]. Till date we have not come across any study that has been shown to provide positive effects in cognition and behavioral outcomes following post-TBI injury events. Therefore, future study is warranted to understand the beneficial effects of probiotic supplementation for patients with TBI injury that could help reduce the mortality rate also.

\section{Future Perspectives and Conclusion}

The eubiotic gut is closely linked with good human health, and an imbalance of the GM either because of HHcy-led dysfunction of the 1-carbon metabolism or any other reason is associated with various system disorders (Figs. 1 and 2) 
[150, 153-156, 192-194]. Because of the importance of bidirectional relationship between the GM and TBI-associated pathophysiology, management of gut dysbiosis could serve as paradigm for a likely therapeutic target (Figs. 1 and 2). Probiotics consisting of butyrate-producing gut bacteria appear to be the most beneficial as a mode of eubiotic therapy that may enhance benefits of GMB axis and its healthpromoting functions through anti-inflammatory and the positive mitochondrial energetic properties (Figs. 3 and 4). Advances in the next-generation sequencing, and bioinformatics tools have revealed an expansive and diverse microbial community that certainly offers a promising avenue for developing new class of therapeutics for a host of medical conditions, including TBI.

It is becoming clear that perturbations in the GM can contribute to neuro-physiological disorders. Thus, a further understanding of the role of GMB axis and its influence on brain and ocular function and its links with neurologic and neurodegenerative disorders will provide not only better treatment options but also superior managemental strategies in the coming future (Figure 5). Coordinated research efforts to understand the mechanism(s) involved in the dysbiosis could help us on how the connectivity between CNS injury, and microbiota regulates the diseases and their outcomes. Insights into these mechanisms could provide further options for early intervention for TBI in patients of all ages. Identification of therapeutic eubiotic microbes and their potential metabolites would offer promise for devising the effective treatment modalities for the patients. Furthermore, pathogenic mutations that cause genetically governed HHcy-related 1 carbon metabolic disorders and the attendant TBI severity and their relationships with intestinal dysbiotic flora remain to be investigated and thus warrant continued investigation.

Acknowledgments Authors thank and acknowledge the help and support of other laboratory members.

Authors' contributions MS conceived the idea of collecting, assembling, and reviewing the literature for this manuscript before finalizing its submission. AKG helped putting the draft of the manuscript along with figure generation. JB, NT, and SCT assisted in developing the framework for the work, while RPH was responsible for language interpretation and sequence arrangement along with reference management for the manuscript. All authors read and approved the final version of this manuscript.

Funding A part of this work was supported by NIH grants AR-71789, HL139047, and DK116591.

\section{Compliance with Ethical Standards}

Conflicting Interests The authors declare no potential conflicts of interest with respect to the research, authorship, and/or publication of this article. Further, the authors received no financial support for the research, authorship, and/or publication of this article.
Availability of Data and Material Data and material pertaining to this manuscript shall be made available as per the journal's guidelines.

Consent to Participate Not applicable.

Consent for Publication Authors consent for the publication of the manuscript.

\section{References}

1. Nolan S (2005) Traumatic brain injury: a review. Crit Care Nurs Q 28(2):188-194. https://doi.org/10.1097/00002727-20050400000010

2. Summers CR, Ivins B, Schwab KA (2009) Traumatic brain injury in the United States: an epidemiologic overview. Mount Sinai J Med N Y 76(2):105-110. https://doi.org/10.1002/msj.20100

3. Prins M, Greco T, Alexander D, Giza CC (2013) The pathophysiology of traumatic brain injury at a glance. Dis Model Mech 6(6): 1307-1315. https://doi.org/10.1242/dmm.011585

4. CDC grand rounds: reducing severe traumatic brain injury in the United States (2013) MMWR Morb Mortal Wkly Rep 62(27): 549-552

5. Coronado VG, McGuire LC, Sarmiento K, Bell J, Lionbarger MR, Jones CD, Geller AI, Khoury N et al (2012) Trends in Traumatic Brain Injury in the U.S. and the public health response: 1995-2009. J Saf Res 43(4):299-307. https://doi.org/10.1016/j.jsr. 2012.08.011

6. Pearson WS, Ovalle F Jr, Faul M, Sasser SM (2012) A review of traumatic brain injury trauma center visits meeting physiologic criteria from The American College of Surgeons Committee on Trauma/Centers for Disease Control and Prevention Field Triage Guidelines. Prehosp Emerg Care 16(3):323-328. https://doi.org/ 10.3109/10903127.2012.682701

7. Viano DC, Parenteau CS, Xu L, Faul M (2017) Head injuries (TBI) to adults and children in motor vehicle crashes. Traffic Injury Prev 18(6):616-622. https://doi.org/10.1080/15389588. 2017.1285023

8. Cohen JS, Gioia G, Atabaki S, Teach SJ (2009) Sports-related concussions in pediatrics. Curr Opin Pediatr 21(3):288-293. https://doi.org/10.1097/MOP.0b013e32832b1195

9. Mac Donald CL, Johnson AM, Wierzechowski L, Kassner E, Stewart T, Nelson EC, Werner NJ, Zonies D et al (2014) Prospectively assessed clinical outcomes in concussive blast vs nonblast traumatic brain injury among evacuated US military personnel. JAMA Neurol 71(8):994-1002. https://doi.org/10.1001/ jamaneurol.2014.1114

10. Bolouri H, Zetterberg H (2015) Frontiers in Neuroengineering Animal Models for Concussion: Molecular and Cognitive Assessments-Relevance to Sport and Military Concussions. In: Kobeissy FH (ed) Brain Neurotrauma: Molecular, Neuropsychological, and Rehabilitation Aspects. CRC Press/ Taylor \& Francis (C) 2015 by Taylor \& Francis Group, LLC, Boca Raton (FL)

11. Namjoshi DR, Good C, Cheng WH, Panenka W, Richards D, Cripton PA, Wellington CL (2013) Towards clinical management of traumatic brain injury: a review of models and mechanisms from a biomechanical perspective. Dis Model Mech 6(6):13251338. https://doi.org/10.1242/dmm.011320

12. Capizzi A, Woo J, Verduzco-Gutierrez M (2020) Traumatic brain injury: an overview of epidemiology, pathophysiology, and medical management. Med Clin N Am 104(2):213-238. https://doi. org/10.1016/j.mcna.2019.11.001 
13. Dixon KJ (2017) Pathophysiology of Traumatic Brain Injury. Phys Med Rehabil Clin N Am 28(2):215-225. https://doi.org/10. 1016/j.pmr.2016.12.001

14. Zhang Y, Wang Z, Peng J, Gerner ST, Yin S, Jiang Y (2021) Gut microbiota-brain interaction: An emerging immunotherapy for traumatic brain injury. Exp Neurol 337:113585. https://doi.org/ 10.1016/j.expneurol.2020.113585

15. Fond G, Boukouaci W, Chevalier G, Regnault A, Eberl G, Hamdani N, Dickerson F, Macgregor A et al (2015) The "psychomicrobiotic": Targeting microbiota in major psychiatric disorders: A systematic review. Pathologie-biologie 63(1):3542. https://doi.org/10.1016/j.patbio.2014.10.003

16. Pirbaglou M, Katz J, de Souza RJ, Stearns JC, Motamed M, Ritvo P (2016) Probiotic supplementation can positively affect anxiety and depressive symptoms: a systematic review of randomized controlled trials. Nutr Res 36(9):889-898. https://doi.org/10. 1016/j.nutres.2016.06.009

17. Wang H, Lee IS, Braun C, Enck P (2016) Effect of Probiotics on Central Nervous System Functions in Animals and Humans: A Systematic Review. J Neurogastroenterol Motil 22(4):589-605. https://doi.org/10.5056/jnm16018

18. Rice MW, Pandya JD, Shear DA (2019) Gut Microbiota as a Therapeutic Target to Ameliorate the Biochemical, Neuroanatomical, and Behavioral Effects of Traumatic Brain Injuries. Front Neurol 10:875. https://doi.org/10.3389/fneur. 2019.00875

19. Kigerl KA, Hall JC, Wang L, Mo X, Yu Z, Popovich PG (2016) Gut dysbiosis impairs recovery after spinal cord injury. J Exp Med 213(12):2603-2620. https://doi.org/10.1084/jem.20151345

20. Jogia T, Ruitenberg MJ (2020) Traumatic Spinal Cord Injury and the Gut Microbiota: Current Insights and Future Challenges. Front Immunol 11:704. https://doi.org/10.3389/fimmu.2020.00704

21. Zhu S, Jiang Y, Xu K, Cui M, Ye W, Zhao G, Jin L, Chen X (2020) The progress of gut microbiome research related to brain disorders. J Neuroinflammation 17(1):25. https://doi.org/10.1186/ s12974-020-1705-Z

22. Wen SW, Wong CHY (2017) An unexplored brain-gut microbiota axis in stroke. Gut Microbes 8(6):601-606. https://doi.org/10. 1080/19490976.2017.1344809

23. Tan BYQ, Paliwal PR, Sharma VK (2020) Gut Microbiota and Stroke. Ann Indian Acad Neurol 23(2):155-158. https://doi.org/ 10.4103/aian.AIAN 48319

24. Durgan DJ, Lee J, McCullough LD, Bryan RM Jr (2019) Examining the Role of the Microbiota-Gut-Brain Axis in Stroke. Stroke 50(8):2270-2277. https://doi.org/10.1161/strokeaha.119. 025140

25. Prame Kumar K, Wong CH (2020) Imbalance in the force: the dark side of the microbiota on stroke risk and progression. Curr Opin Neurobiol 62:10-16. https://doi.org/10.1016/j.conb.2019. 10.002

26. Yi LJ, Tian X, Shi B, Pi YP, Chen WQ (2019) Early enteral nutrition supplemented with probiotics improved the clinical outcomes in severe head injury: Some promising findings from Chinese patients. Medicine 98(17):e15426. https://doi.org/10. 1097/md.0000000000015426

27. Tan M, Zhu JC, Du J, Zhang LM, Yin HH (2011) Effects of probiotics on serum levels of Th1/Th2 cytokine and clinical outcomes in severe traumatic brain-injured patients: a prospective randomized pilot study. Crit Care (London, Engl) 15(6):R290. https://doi.org/10.1186/cc10579

28. Reiner A, Heldt SA, Presley CS, Guley NH, Elberger AJ, Deng Y, D'Surney L, Rogers JT et al (2014) Motor, visual and emotional deficits in mice after closed-head mild traumatic brain injury are alleviated by the novel CB2 inverse agonist SMM-189. Int J Mol Sci 16(1):758-787. https://doi.org/10.3390/ijms16010758
29. Hylin MJ, Holden RC, Smith AC, Logsdon AF, Qaiser R, LuckeWold BP (2018) Juvenile Traumatic Brain Injury Results in Cognitive Deficits Associated with Impaired Endoplasmic Reticulum Stress and Early Tauopathy. Dev Neurosci 40(2): 175-188. https://doi.org/10.1159/000488343

30. Treangen TJ, Wagner J, Burns MP, Villapol S (2018) Traumatic Brain Injury in Mice Induces Acute Bacterial Dysbiosis Within the Fecal Microbiome. Front Immunol 9:2757. https://doi.org/10. 3389/fimmu.2018.02757

31. Menon DK, Schwab K, Wright DW, Maas AI (2010) Position statement: definition of traumatic brain injury. Arch Phys Med Rehabil 91(11):1637-1640. https://doi.org/10.1016/j.apmr.2010. 05.017

32. Majdan M, Plancikova D, Brazinova A, Rusnak M, Nieboer D, Feigin V, Maas A (2016) Epidemiology of traumatic brain injuries in Europe: a cross-sectional analysis. Lancet Public Health 1(2): e76-e83. https://doi.org/10.1016/s2468-2667(16)30017-2

33. Dewan MC, Rattani A, Gupta S, Baticulon RE, Hung YC, Punchak M, Agrawal A, Adeleye AO et al (2018) Estimating the global incidence of traumatic brain injury. J Neurosurg 118. https://doi.org/10.3171/2017.10.Jns17352

34. Dewan S, Schimmel S, Borlongan CV (2018) Treating childhood traumatic brain injury with autologous stem cell therapy. Expert Opin Biol Ther 18(5):515-524. https://doi.org/10.1080/ 14712598.2018.1439473

35. Taylor CA, Bell JM, Breiding MJ, Xu L (2017) Traumatic Brain Injury-Related Emergency Department Visits, Hospitalizations, and Deaths - United States, 2007 and 2013. Morbid Mortal Wkly Rep Surveill Summ 66(9):1-16. https://doi.org/10.15585/ mmwr.ss6609a1

36. Hyder AA, Wunderlich CA, Puvanachandra P, Gururaj G, Kobusingye OC (2007) The impact of traumatic brain injuries: a global perspective. NeuroRehabilitation 22(5):341-353

37. Selassie AW, Zaloshnja E, Langlois JA, Miller T, Jones P, Steiner C (2008) Incidence of long-term disability following traumatic brain injury hospitalization, United States, 2003. J Head Trauma Rehabil 23(2):123-131. https://doi.org/10.1097/01.Htr. 0000314531.30401 .39

38. Zaloshnja E, Miller T, Langlois JA, Selassie AW (2008) Prevalence of long-term disability from traumatic brain injury in the civilian population of the United States, 2005. J Head Trauma Rehabil 23(6):394-400. https://doi.org/10.1097/01.HTR. 0000341435.52004.ac

39. Badri S, Chen J, Barber J, Temkin NR, Dikmen SS, Chesnut RM, Deem S, Yanez ND et al (2012) Mortality and long-term functional outcome associated with intracranial pressure after traumatic brain injury. Intensive Care Med 38(11):1800-1809. https://doi. org/10.1007/s00134-012-2655-4

40. Carney N, Chesnut RM, Maynard H, Mann NC, Patterson P, Helfand M (1999) Effect of cognitive rehabilitation on outcomes for persons with traumatic brain injury: A systematic review. J Head Trauma Rehabil 14(3):277-307. https://doi.org/10.1097/ 00001199-199906000-00008

41. Chesnut RM, Carney N, Maynard H, Mann NC, Patterson P, Helfand M (1999) Summary report: evidence for the effectiveness of rehabilitation for persons with traumatic brain injury. J Head Trauma Rehabil 14(2):176-188. https://doi.org/10.1097/ 00001199-199904000-00007

42. Helmy A, Carpenter KL, Menon DK, Pickard JD, Hutchinson PJ (2011) The cytokine response to human traumatic brain injury: temporal profiles and evidence for cerebral parenchymal production. J Cereb Blood Flow Metab 31(2):658-670. https://doi.org/ $10.1038 / \mathrm{jcbfm} .2010 .142$

43. Burda JE, Bernstein AM, Sofroniew MV (2016) Astrocyte roles in traumatic brain injury. Exp Neurol 275 Pt 3(0 3):305-315. https:// doi.org/10.1016/j.expneurol.2015.03.020 
44. Jassam YN, Izzy S, Whalen M, McGavern DB, El Khoury J (2017) Neuroimmunology of Traumatic Brain Injury: Time for a Paradigm Shift. Neuron 95(6):1246-1265. https://doi.org/10. 1016/j.neuron.2017.07.010

45. Jacobs SM, Van Stavern GP (2013) Neuro-ophthalmic deficits after head trauma. Curr Neurol Neurosci Rep 13(11):389. https:// doi.org/10.1007/s11910-013-0389-5

46. Ahmed S, Venigalla H, Mekala HM, Dar S, Hassan M, Ayub S (2017) Traumatic Brain Injury and Neuropsychiatric Complications. Indian J Psychol Med 39(2):114-121. https://doi. org/10.4103/0253-7176.203129

47. Armstrong RA (2018) Visual problems associated with traumatic brain injury. Clin Exp Optom 101(6):716-726. https://doi.org/10. $1111 /$ cxo. 12670

48. Kline AE, Leary JB, Radabaugh HL, Cheng JP, Bondi CO (2016) Combination therapies for neurobehavioral and cognitive recovery after experimental traumatic brain injury: Is more better? Prog Neurobiol 142:45-67. https://doi.org/10.1016/j.pneurobio.2016. 05.002

49. Pearn ML, Niesman IR, Egawa J, Sawada A, Almenar-Queralt A, Shah SB, Duckworth JL, Head BP (2017) Pathophysiology Associated with Traumatic Brain Injury: Current Treatments and Potential Novel Therapeutics. Cell Mol Neurobiol 37(4):571-585. https://doi.org/10.1007/s10571-016-0400-1

50. Kochanek PM, Bramlett HM, Shear DA, Dixon CE, Mondello S, Dietrich WD, Hayes RL, Wang KK et al (2016) Synthesis of Findings, Current Investigations, and Future Directions: Operation Brain Trauma Therapy. J Neurotrauma 33(6):606614. https://doi.org/10.1089/neu.2015.4133

51. Kharrazian D (2015) Traumatic Brain Injury and the Effect on the Brain-Gut Axis. Altern Ther Health Med 21(Suppl 3):28-32

52. Behera J, Bala J, Nuru M, Tyagi SC, Tyagi N (2017) Homocysteine as a Pathological Biomarker for Bone Disease. J Cell Physiol 232(10):2704-2709. https://doi.org/10.1002/jcp. 25693

53. Maltsev AV, Bystryak S, Galzitskaya OV (2011) The role of $\beta$ amyloid peptide in neurodegenerative diseases. Ageing Res Rev 10(4):440-452. https://doi.org/10.1016/j.arr.2011.03.002

54. Goldsworthy MR, Vallence AM (2013) The role of $\beta$-amyloid in alzheimer's disease-related neurodegeneration. J Neurosci 33(32): 12910-12911. https://doi.org/10.1523/jneurosci.2252-13.2013

55. Garcia A, Zanibbi K (2004) Homocysteine and cognitive function in elderly people. CMAJ: Can Med Assoc J 171(8):897-904. https://doi.org/10.1503/cmaj.1031586

56. Mattson MP (2003) Gene-diet interactions in brain aging and neurodegenerative disorders. Ann Intern Med 139(5 Pt 2):441-444. https://doi.org/10.7326/0003-4819-139-5_part_2-20030902100012

57. Mattson MP, Kruman II, Duan W (2002) Folic acid and homocysteine in age-related disease. Ageing Res Rev 1(1):95-111. https://doi.org/10.1016/s0047-6374(01)00365-7

58. Tjiattas L, Ortiz DO, Dhivant S, Mitton K, Rogers E, Shea TB (2004) Folate deficiency and homocysteine induce toxicity in cultured dorsal root ganglion neurons via cytosolic calcium accumulation. Aging Cell 3(2):71-76. https://doi.org/10.1111/j.14749728.2004.00086.x

59. Nilsson K, Gustafson L, Hultberg B (2007) Elevated plasma homocysteine concentration in elderly patients with mental illness is mainly related to the presence of vascular disease and not the diagnosis. Dement Geriatr Cogn Disord 24(3):162-168. https:// doi.org/10.1159/000105562

60. Kade G, Antosiewicz S, Nowak Z, Wańkowicz Z (2012) Albuminuria and hyperhomocysteinemia as cardiovascular risk factors in potentially healthy soldiers: A long-term observation. Med Sci Monitor 18(12):Cr771-Cr776. https://doi.org/10.12659/ msm. 883638
61. Kamath AF, Chauhan AK, Kisucka J, Dole VS, Loscalzo J, Handy DE, Wagner DD (2006) Elevated levels of homocysteine compromise blood-brain barrier integrity in mice. Blood 107(2): 591-593. https://doi.org/10.1182/blood-2005-06-2506

62. Vegeto E, Bonincontro C, Pollio G, Sala A, Viappiani S, Nardi F, Brusadelli A, Viviani B et al (2001) Estrogen prevents the lipopolysaccharide-induced inflammatory response in microglia. J Neurosci 21(6):1809-1818. https://doi.org/10.1523/jneurosci. 21-06-01809.2001

63. Zou CG, Zhao YS, Gao SY, Li SD, Cao XZ, Zhang M, Zhang KQ (2010) Homocysteine promotes proliferation and activation of microglia. Neurobiol Aging 31(12):2069-2079. https://doi.org/10. 1016/j.neurobiolaging.2008.11.007

64. Banks WA, Erickson MA (2010) The blood-brain barrier and immune function and dysfunction. Neurobiol Dis 37(1):26-32. https://doi.org/10.1016/j.nbd.2009.07.031

65. Tchantchou F, Goodfellow M, Li F, Ramsue L, Miller C, Puche A, Fiskum G (2020) Hyperhomocysteinemia-Induced Oxidative Stress Exacerbates Cortical Traumatic Brain Injury Outcomes in Rats. Cell Mol Neurobiol. https://doi.org/10.1007/s10571-02000866-7

66. Ghorbanihaghjo A, Javadzadeh A, Argani H, Nezami N, Rashtchizadeh N, Rafeey M, Rohbaninoubar M, RahimiArdabili B (2008) Lipoprotein(a), homocysteine, and retinal arteriosclerosis. Mol Vis 14:1692-1697

67. Javadzadeh A, Ghorbanihaghjo A, Bahreini E, Rashtchizadeh N, Argani H, Alizadeh S (2010) Plasma oxidized LDL and thiolcontaining molecules in patients with exudative age-related macular degeneration. Mol Vis 16:2578-2584

68. Gerth C, Morel CF, Feigenbaum A, Levin AV (2008) Ocular phenotype in patients with methylmalonic aciduria and homocystinuria, cobalamin C type. J AAPOS 12(6):591-596. https://doi.org/10.1016/j.jaapos.2008.06.008

69. Micheal S, Qamar R, Akhtar F, Khan MI, Khan WA, Ahmed A (2009) MTHFR gene C677T and A1298C polymorphisms and homocysteine levels in primary open angle and primary closed angle glaucoma. Mol Vis 15:2268-2278

70. Axer-Siegel R, Bourla D, Ehrlich R, Dotan G, Benjamini Y, Gavendo S, Weinberger D, Sela BA (2004) Association of neovascular age-related macular degeneration and hyperhomocysteinemia. Am J Ophthalmol 137(1):84-89. https://doi.org/10. 1016/s0002-9394(03)00864-x

71. Zinno P, Motta V, Guantario B, Natella F, Roselli M, Bello C, Comitato R, Carminati D et al (2020) Supplementation with dairy matrices impacts on homocysteine levels and gut microbiota composition of hyperhomocysteinemic mice. Eur J Nutr 59(1):345358. https://doi.org/10.1007/s00394-019-01911-y

72. Ley RE, Peterson DA, Gordon JI (2006) Ecological and evolutionary forces shaping microbial diversity in the human intestine. Cell 124(4):837-848. https://doi.org/10.1016/j.cell.2006.02.017

73. Atarashi K, Honda K (2011) Microbiota in autoimmunity and tolerance. Curr Opin Immunol 23(6):761-768. https://doi.org/10. 1016/j.coi.2011.11.002

74. Chervonsky AV (2012) Intestinal commensals: influence on immune system and tolerance to pathogens. Curr Opin Immunol 24(3):255-260. https://doi.org/10.1016/j.coi.2012.03.002

75. Paun A, Danska JS (2015) Immuno-ecology: how the microbiome regulates tolerance and autoimmunity. Curr Opin Immunol 37:34 39. https://doi.org/10.1016/j.coi.2015.09.004

76. Frank DN, St Amand AL, Feldman RA, Boedeker EC, Harpaz N, Pace NR (2007) Molecular-phylogenetic characterization of microbial community imbalances in human inflammatory bowel diseases. Proc Natl Acad Sci U S A 104(34):13780-13785. https:// doi.org/10.1073/pnas.0706625104

77. Bibbò S, Dore MP, Pes GM, Delitala G, Delitala AP (2017) Is there a role for gut microbiota in type 1 diabetes pathogenesis? 
Ann Med 49(1):11-22. https://doi.org/10.1080/07853890.2016. 1222449

78. Kasselman LJ, Vernice NA, DeLeon J, Reiss AB (2018) The gut microbiome and elevated cardiovascular risk in obesity and autoimmunity. Atherosclerosis 271:203-213. https://doi.org/10.1016/ j.atherosclerosis.2018.02.036

79. Sohail MU, Althani A, Anwar H, Rizzi R, Marei HE (2017) Role of the Gastrointestinal Tract Microbiome in the Pathophysiology of Diabetes Mellitus. J Diabetes Res 2017:9631435. https://doi. org $/ 10.1155 / 2017 / 9631435$

80. Gavin PG, Mullaney JA, Loo D, Cao KL, Gottlieb PA, Hill MM, Zipris D, Hamilton-Williams EE (2018) Intestinal Metaproteomics Reveals Host-Microbiota Interactions in Subjects at Risk for Type 1 Diabetes. Diabetes Care 41(10): 2178-2186. https://doi.org/10.2337/dc18-0777

81. Beli E, Yan Y, Moldovan L, Vieira CP, Gao R, Duan Y, Prasad R, Bhatwadekar A et al (2018) Restructuring of the Gut Microbiome by Intermittent Fasting Prevents Retinopathy and Prolongs Survival in db/db Mice. Diabetes 67(9):1867-1879. https://doi. org/10.2337/db18-0158

82. Duan Y, Prasad R, Feng D, Beli E, Li Calzi S, Longhini ALF, Lamendella R, Floyd JL et al (2019) Bone Marrow-Derived Cells Restore Functional Integrity of the Gut Epithelial and Vascular Barriers in a Model of Diabetes and ACE2 Deficiency. Circ Res 125(11):969-988. https://doi.org/10.1161/circresaha.119.315743

83. Dinan TG, Cryan JF (2017) Brain-Gut-Microbiota Axis and Mental Health. Psychosom Med 79(8):920-926. https://doi.org/ 10.1097/psy.0000000000000519

84. Cryan JF, Dinan TG (2012) Mind-altering microorganisms: the impact of the gut microbiota on brain and behaviour. Nat Rev Neurosci 13(10):701-712. https://doi.org/10.1038/nrn3346

85. Rhee SH, Pothoulakis C, Mayer EA (2009) Principles and clinical implications of the brain-gut-enteric microbiota axis. Nat Rev Gastroenterol Hepatol 6(5):306-314. https://doi.org/10.1038/ nrgastro.2009.35

86. Collins SM, Surette M, Bercik P (2012) The interplay between the intestinal microbiota and the brain. Nat Rev Microbiol 10(11): 735-742. https://doi.org/10.1038/nrmicro2876

87. Cowan CS, Callaghan BL, Richardson R (2016) The effects of a probiotic formulation (Lactobacillus rhamnosus and L. helveticus) on developmental trajectories of emotional learning in stressed infant rats. Transl Psychiatry 6(5):e823. https://doi.org/10.1038/ tp.2016.94

88. De Palma G, Blennerhassett P, Lu J, Deng Y, Park AJ, Green W, Denou E, Silva MA et al (2015) Microbiota and host determinants of behavioural phenotype in maternally separated mice. Nat Commun 6:7735. https://doi.org/10.1038/ncomms8735

89. Hyland NP, O'Mahony SM, O'Malley D, O'Mahony CM, Dinan TG, Cryan JF (2015) Early-life stress selectively affects gastrointestinal but not behavioral responses in a genetic model of braingut axis dysfunction. Neurogastroenterol Motil 27(1):105-113. https://doi.org/10.1111/nmo.12486

90. Khorjahani A, Peeri M, Azarbayjani MA (2020) The Therapeutic Effect of Exercise on Anxiety and Bowel Oxidative Stress in the Maternal Separation Animal Model. Basic Clin Neurosci 11(1): 69-78. https://doi.org/10.32598/bcn.9.10.450

91. O'Mahony SM, Hyland NP, Dinan TG, Cryan JF (2011) Maternal separation as a model of brain-gut axis dysfunction. Psychopharmacology 214(1):71-88. https://doi.org/10.1007/ s00213-010-2010-9

92. Ren TH, Wu J, Yew D, Ziea E, Lao L, Leung WK, Berman B, Hu PJ et al (2007) Effects of neonatal maternal separation on neurochemical and sensory response to colonic distension in a rat model of irritable bowel syndrome. Am J Physiol Gastrointest Liver Physiol 292(3):G849-G856. https://doi.org/10.1152/ajpgi.00400. 2006
93. Rincel M, Darnaudéry M (2020) Maternal separation in rodents: a journey from gut to brain and nutritional perspectives. Proc Nutr Soc 79(1):113-132. https://doi.org/10.1017/s0029665119000958

94. Savignac HM, Dinan TG, Cryan JF (2011) Resistance to early-life stress in mice: effects of genetic background and stress duration. Front Behav Neurosci 5:13. https://doi.org/10.3389/fnbeh.2011. 00013

95. Mayer EA (2011) Gut feelings: the emerging biology of gut-brain communication. Nat Rev Neurosci 12(8):453-466. https://doi.org/ 10.1038/nrn3071

96. Kudielka BM, Wüst S (2010) Human models in acute and chronic stress: assessing determinants of individual hypothalamuspituitary-adrenal axis activity and reactivity. Stress 13(1):1-14. https://doi.org/10.3109/10253890902874913

97. Tsigos C, Chrousos GP (2002) Hypothalamic-pituitary-adrenal axis, neuroendocrine factors and stress. J Psychosom Res 53(4): 865-871. https://doi.org/10.1016/s0022-3999(02)00429-4

98. Ma Q, Xing C, Long W, Wang HY, Liu Q, Wang RF (2019) Impact of microbiota on central nervous system and neurological diseases: the gut-brain axis. J Neuroinflammation 16(1):53. https://doi.org/10.1186/s12974-019-1434-3

99. Nagpal R, Mainali R, Ahmadi S, Wang S, Singh R, Kavanagh K, Kitzman DW, Kushugulova A et al (2018) Gut microbiome and aging: Physiological and mechanistic insights. Nutr Healthy Aging 4(4):267-285. https://doi.org/10.3233/nha-170030

100. Carabotti M, Scirocco A, Maselli MA, Severi C (2015) The gutbrain axis: interactions between enteric microbiota, central and enteric nervous systems. Ann Gastroenterol 28(2):203-209

101. Mohajeri MH, La Fata G, Steinert RE, Weber P (2018) Relationship between the gut microbiome and brain function. Nutr Rev 76(7):481-496. https://doi.org/10.1093/nutrit/nuy009

102. Tengeler AC, Kozicz T, Kiliaan AJ (2018) Relationship between diet, the gut microbiota, and brain function. Nutr Rev 76(8):603617. https://doi.org/10.1093/nutrit/nuy016

103. Sampson TR, Debelius JW, Thron T, Janssen S, Shastri GG, Ilhan ZE, Challis C, Schretter CE et al (2016) Gut Microbiota Regulate Motor Deficits and Neuroinflammation in a Model of Parkinson's Disease. Cell 167(6):1469-1480.e1412. https://doi.org/10.1016/j. cell.2016.11.018

104. Sampson TR, Mazmanian SK (2015) Control of brain development, function, and behavior by the microbiome. Cell Host Microbe 17(5):565-576. https://doi.org/10.1016/j.chom.2015.04. 011

105. Sharon G, Sampson TR, Geschwind DH, Mazmanian SK (2016) The Central Nervous System and the Gut Microbiome. Cell 167(4):915-932. https://doi.org/10.1016/j.cell.2016.10.027

106. Horai R, Zárate-Bladés CR, Dillenburg-Pilla P, Chen J, Kielczewski JL, Silver PB, Jittayasothorn Y, Chan CC et al (2015) Microbiota-Dependent Activation of an Autoreactive T Cell Receptor Provokes Autoimmunity in an Immunologically Privileged Site. Immunity 43(2):343-353. https://doi.org/10. 1016/j.immuni.2015.07.014

107. Nakamura YK, Metea C, Karstens L, Asquith M, Gruner H, Moscibrocki C, Lee I, Brislawn CJ et al (2016) Gut Microbial Alterations Associated With Protection From Autoimmune Uveitis. Invest Ophthalmol Vis Sci 57(8):3747-3758. https://doi. org/10.1167/iovs.16-19733

108. Janowitz C, Nakamura YK, Metea C, Gligor A, Yu W, Karstens L, Rosenbaum JT, Asquith M et al (2019) Disruption of Intestinal Homeostasis and Intestinal Microbiota During Experimental Autoimmune Uveitis. Invest Ophthalmol Vis Sci 60(1):420-429. https://doi.org/10.1167/iovs.18-24813

109. Heissigerova J, Seidler Stangova P, Klimova A, Svozilkova P, Hrncir T, Stepankova R, Kverka M, Tlaskalova-Hogenova H et al (2016) The Microbiota Determines Susceptibility to 
Experimental Autoimmune Uveoretinitis. J Immunol Res 2016: 5065703. https://doi.org/10.1155/2016/5065703

110. Klimova A, Seidler Stangova P, Svozilkova P, Forrester JV, Klaska I, Heissigerova J (2016) The critical points in induction of experimental autoimmune uveitis. Biomed Pap Med Fac Univ Palacky Olomouc Czech 160(1):140-142. https://doi.org/10. 5507/bp.2015.056

111. Huang X, Ye Z, Cao Q, Su G, Wang Q, Deng J, Zhou C, Kijlstra A et al (2018) Gut Microbiota Composition and Fecal Metabolic Phenotype in Patients With Acute Anterior Uveitis. Invest Ophthalmol Vis Sci 59(3):1523-1531. https://doi.org/10.1167/ iovs. 17-22677

112. Ye Z, Zhang N, Wu C, Zhang X, Wang Q, Huang X, Du L, Cao Q et al (2018) A metagenomic study of the gut microbiome in Behcet's disease. Microbiome 6(1):135. https://doi.org/10.1186/ s40168-018-0520-6

113. Aguilar-Valles A, Inoue W, Rummel C, Luheshi GN (2015) Obesity, adipokines and neuroinflammation. Neuropharmacology 96(Pt A):124-134. https://doi.org/10.1016/ j.neuropharm.2014.12.023

114. Byrne ML, O'Brien-Simpson NM, Mitchell SA, Allen NB (2015) Adolescent-Onset Depression: Are Obesity and Inflammation Developmental Mechanisms or Outcomes? Child Psychiatry Hum Dev 46(6):839-850. https://doi.org/10.1007/s10578-0140524-9

115. Severance EG, Alaedini A, Yang S, Halling M, Gressitt KL, Stallings CR, Origoni AE, Vaughan C et al (2012) Gastrointestinal inflammation and associated immune activation in schizophrenia. Schizophr Res 138(1):48-53. https://doi.org/10. 1016/j.schres.2012.02.025

116. Ozdemir V, Jamal MM, Osapay K, Jadus MR, Sandor Z, Hashemzadeh M, Szabo S (2007) Cosegregation of gastrointestinal ulcers and schizophrenia in a large national inpatient discharge database: revisiting the "brain-gut axis" hypothesis in ulcer pathogenesis. J Investig Med 55(6):315-320. https://doi.org/10.2310/ 6650.2007 .00014

117. Biagi E, Nylund L, Candela M, Ostan R, Bucci L, Pini E, Nikkïla J, Monti D et al (2010) Through ageing, and beyond: gut microbiota and inflammatory status in seniors and centenarians. PLoS One 5(5):e10667. https://doi.org/10.1371/journal.pone.0010667

118. Claesson MJ, Cusack S, O'Sullivan O, Greene-Diniz R, de Weerd H, Flannery E, Marchesi JR, Falush D et al (2011) Composition, variability, and temporal stability of the intestinal microbiota of the elderly. Proc Natl Acad Sci U S A 108(Suppl 1):4586-4591. https://doi.org/10.1073/pnas.1000097107

119. Salthouse TA (2009) Decomposing age correlations on neuropsychological and cognitive variables. J Int Neuropsychol Soc 15(5): 650-661. https://doi.org/10.1017/s1355617709990385

120. Schaffer S, Asseburg H, Kuntz S, Muller WE, Eckert GP (2012) Effects of polyphenols on brain ageing and Alzheimer's disease: focus on mitochondria. Mol Neurobiol 46(1):161-178. https://doi. org/10.1007/s12035-012-8282-9

121. Caracciolo B, Xu W, Collins S, Fratiglioni L (2014) Cognitive decline, dietary factors and gut-brain interactions. Mech Ageing Dev 136-137:59-69. https://doi.org/10.1016/j.mad.2013.11.011

122. Hill JM, Clement C, Pogue AI, Bhattacharjee S, Zhao Y, Lukiw WJ (2014) Pathogenic microbes, the microbiome, and Alzheimer's disease (AD). Front Aging Neurosci 6:127. https://doi.org/10. 3389/fnagi.2014.00127

123. Zhao Y, Dua P, Lukiw WJ (2015) Microbial Sources of Amyloid and Relevance to Amyloidogenesis and Alzheimer's Disease (AD). J Alzheim Dis Parkinsonism 5(1):177. https://doi.org/10. 4172/2161-0460.1000177

124. Bhattacharjee S, Lukiw WJ (2013) Alzheimer's disease and the microbiome. Front Cell Neurosci 7:153. https://doi.org/10.3389/ fncel.2013.00153
125. Ghaisas S, Maher J, Kanthasamy A (2016) Gut microbiome in health and disease: Linking the microbiome-gut-brain axis and environmental factors in the pathogenesis of systemic and neurodegenerative diseases. Pharmacol Ther 158:52-62. https://doi.org/ 10.1016/j.pharmthera.2015.11.012

126. de Theije CG, Wopereis H, Ramadan M, van Eijndthoven T, Lambert J, Knol J, Garssen J, Kraneveld AD et al (2014) Altered gut microbiota and activity in a murine model of autism spectrum disorders. Brain Behav Immun 37:197-206. https://doi. org/10.1016/j.bbi.2013.12.005

127. Hsiao EY, McBride SW, Hsien S, Sharon G, Hyde ER, McCue T, Codelli JA, Chow J et al (2013) Microbiota modulate behavioral and physiological abnormalities associated with neurodevelopmental disorders. Cell 155(7):1451-1463. https:// doi.org/10.1016/j.cell.2013.11.024

128. Douglas-Escobar M, Elliott E, Neu J (2013) Effect of intestinal microbial ecology on the developing brain. JAMA Pediatr 167(4): 374-379. https://doi.org/10.1001/jamapediatrics.2013.497

129. Mulle JG, Sharp WG, Cubells JF (2013) The gut microbiome: a new frontier in autism research. Curr Psychiatr Rep 15(2):337. https://doi.org/10.1007/s11920-012-0337-0

130. Macfabe DF (2012) Short-chain fatty acid fermentation products of the gut microbiome: implications in autism spectrum disorders. Microb Ecol Health Dis 23. https://doi.org/10.3402/mehd.v23i0. 19260

131. Fung TC, Olson CA, Hsiao EY (2017) Interactions between the microbiota, immune and nervous systems in health and disease. Nat Neurosci 20(2):145-155. https://doi.org/10.1038/nn.4476

132. Scheperjans F, Aho V, Pereira PA, Koskinen K, Paulin L, Pekkonen E, Haapaniemi E, Kaakkola S et al (2015) Gut microbiota are related to Parkinson's disease and clinical phenotype. Mov Disord 30(3):350-358. https://doi.org/10.1002/mds.26069

133. Keshavarzian A, Green SJ, Engen PA, Voigt RM, Naqib A, Forsyth CB, Mutlu E, Shannon KM (2015) Colonic bacterial composition in Parkinson's disease. Mov Disord 30(10):13511360. https://doi.org/10.1002/mds.26307

134. Lin P (2019) Importance of the intestinal microbiota in ocular inflammatory diseases: A review. Clin Exp Ophthalmol 47(3): 418-422. https://doi.org/10.1111/ceo.13493

135. Floyd JL, Grant MB (2020) The Gut-Eye Axis: Lessons Learned from Murine Models. Ophthalmol Therapy 9(3):499-513. https:// doi.org/10.1007/s40123-020-00278-2

136. Bansal V, Costantini T, Kroll L, Peterson C, Loomis W, Eliceiri B, Baird A, Wolf P et al (2009) Traumatic brain injury and intestinal dysfunction: uncovering the neuro-enteric axis. J Neurotrauma 26(8):1353-1359. https://doi.org/10.1089/neu.2008.0858

137. Hang CH, Shi JX, Li JS, Wu W, Yin HX (2003) Alterations of intestinal mucosa structure and barrier function following traumatic brain injury in rats. World J Gastroenterol 9(12):2776-2781. https://doi.org/10.3748/wjg.v9.i12.2776

138. Rodríguez-Fandiño O, Hernández-Ruíz J, López-Vidal Y, Charúa L, Bandeh-Moghaddam H, Minzoni A, Guzmán C, Schmulson M (2013) Intestinal recruiting and activation profiles in peripheral blood mononuclear cells in response to pathogen-associated molecular patterns stimulation in patients with IBS. Neurogastroenterol Motil 25(11):872-e699. https://doi.org/10. 1111/nmo.12204

139. Li H, Sun J, Du J, Wang F, Fang R, Yu C, Xiong J, Chen W et al (2018) Clostridium butyricum exerts a neuroprotective effect in a mouse model of traumatic brain injury via the gut-brain axis. Neurogastroenterol Motil 30(5):e13260. https://doi.org/10.1111/ nmo. 13260

140. Lu J, Goh SJ, Tng PY, Deng YY, Ling EA, Moochhala S (2009) Systemic inflammatory response following acute traumatic brain injury. Front Biosci (Landm Ed) 14:3795-3813. https://doi.org/ $10.2741 / 3489$ 
141. Wang HX, Wang YP (2016) Gut Microbiota-brain Axis. Chin Med J 129(19):2373-2380. https://doi.org/10.4103/0366-6999. 190667

142. Sundman MH, Chen NK, Subbian V, Chou YH (2017) The bidirectional gut-brain-microbiota axis as a potential nexus between traumatic brain injury, inflammation, and disease. Brain Behav Immun 66:31-44. https://doi.org/10.1016/j.bbi.2017.05.009

143. Houlden A, Goldrick M, Brough D, Vizi ES, Lénárt N, Martinecz B, Roberts IS, Denes A (2016) Brain injury induces specific changes in the caecal microbiota of mice via altered autonomic activity and mucoprotein production. Brain Behav Immun 57:10 20. https://doi.org/10.1016/j.bbi.2016.04.003

144. Moos WH, Faller DV, Harpp DN, Kanara I, Pernokas J, Powers WR, Steliou K (2016) Microbiota and Neurological Disorders: A Gut Feeling. BioResearch Open Access 5(1):137-145. https://doi. org/10.1089/biores.2016.0010

145. Winek K, Engel O, Koduah P, Heimesaat MM, Fischer A, Bereswill S, Dames C, Kershaw O et al (2016) Depletion of Cultivatable Gut Microbiota by Broad-Spectrum Antibiotic Pretreatment Worsens Outcome After Murine Stroke. Stroke 47(5):1354-1363. https://doi.org/10.1161/strokeaha.115.011800

146. Winek K, Meisel A, Dirnagl U (2016) Gut microbiota impact on stroke outcome: Fad or fact? J Cerebr Blood Flow Metab 36(5): 891-898. https://doi.org/10.1177/0271678x16636890

147. Kigerl KA, Mostacada K, Popovich PG (2018) Gut Microbiota Are Disease-Modifying Factors After Traumatic Spinal Cord Injury. Neurotherapeutics 15(1):60-67. https://doi.org/10.1007/ s13311-017-0583-2

148. Nicholson SE, Watts LT, Burmeister DM, Merrill D, Scroggins S, Zou Y, Lai Z, Grandhi R et al (2019) Moderate Traumatic Brain Injury Alters the Gastrointestinal Microbiome in a TimeDependent Manner. Shock (Augusta, Ga) 52(2):240-248. https://doi.org/10.1097/shk.0000000000001211

149. Howard BM, Kornblith LZ, Christie SA, Conroy AS, Nelson MF, Campion EM, Callcut RA, Calfee CS et al (2017) Characterizing the gut microbiome in trauma: significant changes in microbial diversity occur early after severe injury. Trauma Surg Acute Care Open 2(1):e000108. https://doi.org/10.1136/tsaco-2017000108

150. Stanisic D, Jovanovic M, George AK, Homme RP, Tyagi N, Tyagi SC, Singh M (2020) Gut microbiota and the periodontal disease: role of hyperhomocysteinemia. Can J Physiol Pharmacol. https://doi.org/10.1139/cjpp-2020-0215

151. Rizowy GM, Poloni S, Colonetti K, Donis KC, Dobbler PT, Leistner-Segal S, Roesch LFW, Schwartz IVD (2020) Is the gut microbiota dysbiotic in patients with classical homocystinuria? Biochimie 173:3-11. https://doi.org/10.1016/j.biochi.2020.02. 013

152. Cristoni S, Rossi Bernardi L, Larini M, Natale G, Didomenico N, Varelli M, Conti M, Dorna I et al (2019) Predicting and preventing intestinal dysbiosis on the basis of pharmacological gut microbiota metabolism. Rapid Commun Mass Spectrometr 33(14):12211225. https://doi.org/10.1002/rcm.8461

153. Molnar J, Mallonee CJ, Stanisic D, Homme RP, George AK, Singh M, Tyagi SC (2020) Hidradenitis Suppurativa and 1Carbon Metabolism: Role of Gut Microbiome, Matrix Metalloproteinases, and Hyperhomocysteinemia. Front Immunol 11:1730. https://doi.org/10.3389/fimmu.2020.01730

154. George AK, Singh M, Pushpakumar S, Homme RP, Hardin SJ, Tyagi SC (2020) Dysbiotic 1-carbon metabolism in cardiac muscle remodeling. J Cell Physiol 235(3):2590-2598. https://doi.org/ $10.1002 /$ jcp. 29163

155. Laha A, Majumder A, Singh M, Tyagi SC (2018) Connecting homocysteine and obesity through pyroptosis, gut microbiome, epigenetics, peroxisome proliferator-activated receptor $\gamma$, and zinc finger protein 407. Can J Physiol Pharmacol 96(10):971-976. https://doi.org/10.1139/cjpp-2018-0037

156. Tyagi SC, Stanisic D, Singh M (2020) Epigenetic memory: gene writer, eraser and homocysteine. Mol Cell Biochem. https://doi. org/10.1007/s11010-020-03895-4

157. Lindholm D, Castrén E, Kiefer R, Zafra F, Thoenen H (1992) Transforming growth factor-beta 1 in the rat brain: increase after injury and inhibition of astrocyte proliferation. J Cell Biol 117(2): 395-400. https://doi.org/10.1083/jcb.117.2.395

158. Lewén A, Söderström S, Hillered L, Ebendal T (1997) Expression of serine/threonine kinase receptors in traumatic brain injury. Neuroreport 8(2):475-479. https://doi.org/10.1097/00001756199701200-00020

159. Huang RQ, Cheng HL, Zhao XD, Dai W, Zhuang Z, Wu Y, Liu Y, Shi JX (2010) Preliminary study on the effect of traumainduced secondary cellular hypoxia in brain injury. Neurosci Lett 473(1):22-27. https://doi.org/10.1016/j.neulet.2010.02.011

160. Komuta Y, Teng X, Yanagisawa H, Sango K, Kawamura K, Kawano H (2010) Expression of transforming growth factorbeta receptors in meningeal fibroblasts of the injured mouse brain. Cell Mol Neurobiol 30(1):101-111. https://doi.org/10.1007/ s10571-009-9435-x

161. Schachtrup C, Ryu JK, Helmrick MJ, Vagena E, Galanakis DK, Degen JL, Margolis RU, Akassoglou K (2010) Fibrinogen triggers astrocyte scar formation by promoting the availability of active TGF-beta after vascular damage. J Neurosci 30(17):5843-5854. https://doi.org/10.1523/jneurosci.0137-10.2010

162. Logan TT, Villapol S, Symes AJ (2013) TGF- $\beta$ superfamily gene expression and induction of the Runx1 transcription factor in adult neurogenic regions after brain injury. PLoS One 8(3):e59250. https://doi.org/10.1371/journal.pone.0059250

163. Chen J, Van Gulden S, McGuire TL, Fleming AC, Oka C, Kessler JA, Peng CY (2018) BMP-Responsive Protease HtrA1 Is Differentially Expressed in Astrocytes and Regulates Astrocytic Development and Injury Response. J Neurosci 38(15):3840 3857. https://doi.org/10.1523/jneurosci.2031-17.2018

164. Buss A, Pech K, Kakulas BA, Martin D, Schoenen J, Noth J, Brook GA (2008) TGF-beta1 and TGF-beta2 expression after traumatic human spinal cord injury. Spinal Cord 46(5):364-371. https://doi.org/10.1038/sj.sc.3102148

165. Setoguchi T, Yone K, Matsuoka E, Takenouchi H, Nakashima K, Sakou T, Komiya S, Izumo S (2001) Traumatic injury-induced BMP7 expression in the adult rat spinal cord. Brain Res 921(12):219-225. https://doi.org/10.1016/s0006-8993(01)03123-7

166. Hampton DW, Asher RA, Kondo T, Steeves JD, Ramer MS, Fawcett JW (2007) A potential role for bone morphogenetic protein signalling in glial cell fate determination following adult central nervous system injury in vivo. Eur J Neurosci 26(11):3024 3035. https://doi.org/10.1111/j.1460-9568.2007.05940.x

167. Zhang Z, Trautmann K, Artelt M, Burnet M, Schluesener HJ (2006) Bone morphogenetic protein-6 is expressed early by activated astrocytes in lesions of rat traumatic brain injury. Neuroscience 138(1):47-53. https://doi.org/10.1016/j. neuroscience.2005.11.036

168. Martinez G, Carnazza ML, Di Giacomo C, Sorrenti V, Vanella A (2001) Expression of bone morphogenetic protein-6 and transforming growth factor-betal in the rat brain after a mild and reversible ischemic damage. Brain Res 894(1):1-11. https://doi. org/10.1016/s0006-8993(00)03140-1

169. Gumienny TL, Savage-Dunn C (2013) TGF- $\beta$ signaling in C. elegans. WormBook : the online review of $\mathrm{C}$ elegans biology. 1-34. https://doi.org/10.1895/wormbook.1.22.2

170. Dalfó D, Michaelson D, Hubbard EJ (2012) Sensory regulation of the $C$. elegans germline through TGF- $\beta$-dependent signaling in the niche. Curr Biol 22(8):712-719. https://doi.org/10.1016/j. cub.2012.02.064 
171. Goszczynski B, Captan VV, Danielson AM, Lancaster BR, McGhee JD (2016) A 44 bp intestine-specific hermaphrodite-specific enhancer from the $\mathrm{C}$. elegans vit-2 vitellogenin gene is directly regulated by ELT-2, MAB-3, FKH-9 and DAF-16 and indirectly regulated by the germline, by daf-2/insulin signaling and by the TGF- $\beta /$ Sma/Mab pathway. Dev Biol 413(1):112-127. https://doi.org/10.1016/j.ydbio.2016.02.031

172. Wang J, Mohler WA, Savage-Dunn C (2005) C-terminal mutants of C. elegans Smads reveal tissue-specific requirements for protein activation by TGF-beta signaling. Development (Camb, Engl) 132(15):3505-3513. https://doi.org/10.1242/dev.01930

173. Clark JF, Meade M, Ranepura G, Hall DH, Savage-Dunn C (2018) Caenorhabditis elegans DBL-1/BMP Regulates Lipid Accumulation via Interaction with Insulin Signaling. G3 (Bethesda, Md) 8(1):343-351. https://doi.org/10.1534/g3.117. 300416

174. Liang J, Yu L, Yin J, Savage-Dunn C (2007) Transcriptional repressor and activator activities of SMA-9 contribute differentially to BMP-related signaling outputs. Dev Biol 305(2):714-725. https://doi.org/10.1016/j.ydbio.2007.02.038

175. Madaan U, Yzeiraj E, Meade M, Clark JF, Rushlow CA, SavageDunn C (2018) BMP Signaling Determines Body Size via Transcriptional Regulation of Collagen Genes in Caenorhabditis elegans. Genetics 210(4):1355-1367. https://doi.org/10.1534/ genetics.118.301631

176. Savage-Dunn C (2001) Targets of TGF beta-related signaling in Caenorhabditis elegans. Cytokine Growth Factor Rev 12(4):305312. https://doi.org/10.1016/s1359-6101(01)00015-6

177. Savage-Dunn C (2005) TGF-beta signaling. WormBook : the online review of C elegans biology. 1-12. https://doi.org/10.1895/ wormbook.1.22.1

178. Savage-Dunn C, Padgett RW (2017) The TGF- $\beta$ Family in Caenorhabditis elegans. Cold Spring Harb Perspect Biol 9(6). https://doi.org/10.1101/cshperspect.a022178

179. Savage-Dunn C, Yu L, Gill K, Awan M, Fernando T (2011) Nonstringent tissue-source requirements for BMP ligand expression in regulation of body size in Caenorhabditis elegans. Genet Res 93(6):427-432. https://doi.org/10.1017/s0016672311000310

180. Mallo GV, Kurz CL, Couillault C, Pujol N, Granjeaud S, Kohara Y, Ewbank JJ (2002) Inducible antibacterial defense system in C. elegans. Curr Biol 12(14):1209-1214. https://doi.org/10.1016/ s0960-9822(02)00928-4

181. Portal-Celhay C, Bradley ER, Blaser MJ (2012) Control of intestinal bacterial proliferation in regulation of lifespan in Caenorhabditis elegans. BMC Microbiol 12:49. https://doi.org/ 10.1186/1471-2180-12-49

182. Berg M, Monnin D, Cho J, Nelson L, Crits-Christoph A, Shapira M (2019) TGF $\beta / B M P$ immune signaling affects abundance and function of C. elegans gut commensals. Nat Commun 10(1):604. https://doi.org/10.1038/s41467-019-08379-8

183. Singh V, Roth S, Llovera G, Sadler R, Garzetti D, Stecher B, Dichgans M, Liesz A (2016) Microbiota Dysbiosis Controls the Neuroinflammatory Response after Stroke. J Neurosci 36(28): 7428-7440. https://doi.org/10.1523/jneurosci.1114-16.2016
184. Erny D, Hrabě de Angelis AL, Jaitin D, Wieghofer P, Staszewski O, David E, Keren-Shaul H, Mahlakoiv T et al (2015) Host microbiota constantly control maturation and function of microglia in the CNS. Nat Neurosci 18(7):965-977. https://doi.org/10.1038/ nn. 4030

185. Han B, Sivaramakrishnan P, Lin CJ, Neve IAA, He J, Tay LWR, Sowa JN, Sizovs A et al (2017) Microbial Genetic Composition Tunes Host Longevity. Cell 169(7):1249-1262.e1213. https://doi. org/10.1016/j.cell.2017.05.036

186. Cavaleri F, Bashar E (2018) Potential Synergies of $\beta$ Hydroxybutyrate and Butyrate on the Modulation of Metabolism, Inflammation, Cognition, and General Health. J Nutr Metab 2018:7195760. https://doi.org/10.1155/2018/ 7195760

187. Lu J, Frerich JM, Turtzo LC, Li S, Chiang J, Yang C, Wang X, Zhang C et al (2013) Histone deacetylase inhibitors are neuroprotective and preserve NGF-mediated cell survival following traumatic brain injury. Proc Natl Acad Sci U S A 110(26):1074710752. https://doi.org/10.1073/pnas.1308950110

188. Sun J, Wang F, Ling Z, Yu X, Chen W, Li H, Jin J, Pang M et al (2016) Clostridium butyricum attenuates cerebral ischemia/ reperfusion injury in diabetic mice via modulation of gut microbiota. Brain Res 1642:180-188. https://doi.org/10.1016/j.brainres. 2016.03.042

189. Cheng FS, Pan D, Chang B, Jiang M, Sang LX (2020) Probiotic mixture VSL\#3: An overview of basic and clinical studies in chronic diseases. World J Clin Cases 8(8):1361-1384. https:// doi.org/10.12998/wjcc.v8.i8.1361

190. Kumar M, Kissoon-Singh V, Coria AL, Moreau F, Chadee K (2017) Probiotic mixture VSL\#3 reduces colonic inflammation and improves intestinal barrier function in Muc2 mucin-deficient mice. Am J Physiol Gastrointest Liver Physiol 312(1):G34-g45. https://doi.org/10.1152/ajpgi.00298.2016

191. Pavelescu D, Mirea L, Grintescu I (2014) Could selected probiotics have beneficial effects on clinical outcome of severe traumatic brain injury patients? Crit Care 18(1):P472. https://doi. org/10.1186/cc13662

192. George AK, Majumder A, Ice H, Homme RP, Eyob W, Tyagi SC, Singh M (2020) Genes and genetics in hyperhomocysteinemia and the "1-carbon metabolism": implications for retinal structure and eye functions. Can J Physiol Pharmacol 98(2):51-60. https:// doi.org/10.1139/cjpp-2019-0236

193. Singh M, George AK, Eyob W, Homme RP, Stanisic D, Tyagi SC (2020) High methionine diet in skeletal muscle remodeling: Epigenetic mechanism of homocysteine mediated growth retardation. Can J Physiol Pharmacol. https://doi.org/10.1139/cjpp-20200093

194. Stanisic D, George AK, Smolenkova I, Tyagi SC, Singh M (2020) Hyperhomocysteinemia: an instigating factor for periodontal disease. Can J Physiol Pharmacol. https://doi.org/10.1139/cjpp2020-0224

Publisher's Note Springer Nature remains neutral with regard to jurisdictional claims in published maps and institutional affiliations. 